\title{
EFFECT OF MONENSIN AND PROPYLENE GLYCOL AS A PROPHYLACTIC TOOLS FROM CAPRINE LAMB LOSSES AND THERE EFFECTS ON CONCEPTION RATES
}

\author{
HOWIDA, S.M.B. ${ }^{*}$ and R.H. OSMAN** \\ ${ }^{*}$ Dept. of Biology, Animal Reproduction Research Institute, Gizza, Egypt. \\ ${ }^{* *}$ Artificial insemination, Animal Reproduction Research Institute, Gizza, Egypt.
}

\section{ABSTRACT}

Received at: 12/8/2012

Accepted: 31/10/2012
Thirty does at the late stage of pregnancy were used in this study, aged 3-5 years and housed under the same environmental conditions in the same locality (Cairoalexandria desert area). All does were given antiparasitic treatment for external and internal parasites. The does were divided into 3 groups, group1 $(\mathrm{N}=10)$ used as a control group, group $2(\mathrm{~N}=10)$ supplemented with monensin extract as a premix in a dose of $2.72 \mathrm{mg} / \mathrm{head} /$ day for 15 successive days. Group $3(\mathrm{~N}=10)$ were drenched with propylene glycol in a dose of $100 \mathrm{ml} / \mathrm{head} /$ day for 15 successive days. The treatment was done at the beginning of $4^{\text {th }}$ month of pregnancy. Serum samples were analysed from all treated and control groups for blood level of glucose, urea, calcium, triglyceride, total cholesterol, inorganic phosphorous, BHB, NEFA, insulin, liver enzymes and thyroid hormones. Present results revealed that elevation of serum calcium, cholesterol, insulin, glucose, BHB and NEFA in propylene treated group while liver enzymes, total triglycerides and thyroid hormones was decreased followed by monensin treated group in the same manner. The study also illustrated shortened postpartum open days in propylene treated group followed by monensin treated group. while conception rates was significantly increased in propylene drenched group. The study preferred uses of propylene glycol and monensin extract for pregnant does at the late stage of pregnancy for prophylaxis of lamb losses and also for enhancing some fertility parameters.

Key words: Monensin, lamb, Fertility Parameters.

\section{INTRODUCTION}

Does are susceptible to severe hypoglycemia and ketosis during the last few weeks of pregnancy, mostly when the does are with twins or triplets (Cheema et al., 1985 and El-Sebaie et al., 1992). Furthermore, it is believed that pregnancy toxemia occurs when does cannot meet the glucose demand to face the increased requirement for rapidly growing fetuses and then hypoglycemia and ketosis develop (Marteniuk and herdt, 1988; Blood and Radositis, 1991).

There was individual variation in the susceptibility and may be basic difference in glucose metabolism between susceptible and non-susceptible animals (Bergman, 1973). The disease is usually seen as an outbreak, when there is inadequate nutrition available or reduction in food intake (Kronfeld, 1972). Less food may be consumed as pregnancy advances because the conceptus occupies abdominal space (Bergman, 1973).

Moreover, intra-abdominal fat diminishes alimentary capacity, thus a pregnant goat specially more fat or carrying twins, consumes less feed just she needs more (kronfeld, 1972). Recently, epidemiological studies have evaluated the factors affecting the occurrence of pregnancy toxemia and were identified as increasing the risk of the disease. These factors are under nutrition, obesity, ruminal foreign body and inadequate weather (El-Sebaie et al., 1992). Pregnancy toxemia in goats is characterized by a syndrome of inappetence, depression, recumbency, and finally coma (Kronfeld, 1972; Bergman, 1973; Heitzman and Herriman, 1977; El-Sebaie et al., 1992).

Monensin is a polyether carboxylic ionophore produced by streptomyces cinnamonesis (Haney and Hoehn, 1967). Ionophores, as feed additives, have been used widely in the beef industry since 1977 to control coccidiosis and improve feed efficiency (Tyler et al., 1992). Monensin shifts the microbial population in the rumen (Bergen and Bates, 1984). By selectively inhibiting gram-positive bacteria rather than gramnegative bacteria due to differences in bacterial cell wall structure. Monensin alters the flux of monovalent ions across the membranes of gram-positive bacteria, disrupting their normal function and causing them to lyse (Duffield and Bagg, 2000). 
The effects of monensin supplementation include increased ruminal propionate production and reduction of the ruminal acetate/propionate ratio (Van Maanan et al., 1978). Reduced production of methane (Bartley et al., 1979), increased dry matter and starch digestibility, decreased production of bacterial protein (Schelling, 1984), and increase flow of amino acids in the duodenum (Haimoud et al., 1995).

The Propylene glycol is a glucogenic precursor that has been used for many years for both treatment and prevention of ketosis before and after parturition. The majority of propylene escapes the rumen intact; a portion is metabolized to propionate (Emery et al., 1964). Propylene glycol escaping rumen fermentation is converted to glucose by the liver, primarily via the lactaldehyde pathway and subsequent oxidation to lactate (Miller and Bazzano, 1965). Propylene glycol via drenching or feeding was demonstrated by (Johnson, 1954) to treat ketosis effectively in dairy cows because of its glucogenic property (Hanzlik et al., 1939). Propylene glycol has been shown to increase the concentration of propionate and decrease the ratio of acetate to propionate, thereby resulting in a ruminal VFA pattern that is more glucogenic (Czerkawski and Breckenridge, 1972). Supplementation of propylene to cows has been shown to increase blood insulin and glucose concentrations (Christensen et al., 1997). A drench dose of approximately $500 \mathrm{~mL} / \mathrm{d}$ or more is often used as a prophylactic treatment for clinical ketosis in dairy cows (Herdt and Emery, 1992). A lower amount of propylene (e.g., $118 \mathrm{~mL} / \mathrm{d}$ ), however, is often drenched to cows after parturition as a preventive for subclinical ketosis. Replacing routine drenching with feeding can reduce stress on the cow and on the person, who does the drenching, reduce the cost of labour, and ultimately improve the overall health and production of dairy cows.

The aim of this study was to detect how to prophylactic the caprine lamb losses in does by using different regimes in the last stage of pregnancy.

\section{MATERIALS and METHODS}

\section{Animals}

This studies was carried out on 30 balady does of 3-5 years age at the late stage of pregnancy (4-5 month). All of them were subjected to reproductive ultrasonographical scanning for pregnancy diagnosis and it was found that most of them carried 2-3 foeti. All does were belonged to several private sectors of caprine flocks obtained from one locality (high way dessert farms).

All animals were given prophylactic treatment against internal and external parasites. The does were fed on irregular non commercial formulated feed stuffs. The ration generally composed of barseem, hay, grass and sometimes concentrates.

The does were divide into 3 groups, group $1(n=10)$ used as a control group, group $2 \quad(n=10)$ was administrated with monensin sodium (elanco Products, aukland, New Zeland) in the form of premix that contained $10 \%$ monensin sodium in a dose of 2.72 $\mathrm{mg} / \mathrm{kg} \mathrm{B.W}$. for 15 successive days, group $3(\mathrm{n}=10)$ were fed with propylene glycol in a dose of $100 \mathrm{ml}$ polypropylene glycol as a drench (Chanatol, China Co.) for 15 successive days.

\section{Sampling}

Blood samples were collected through jugular vein puncture from each doe. Serum was used for measuring glucose, blood urea nitrogen, total triglycerides, total cholesterol, calcium, inorganic phosphorus, insulin, T3 and T4, serum transaminases (ALT\&AST) according to the methods described by, Mgtowan et al. (1983); Zapletal (1967); Watson (1960); Sakar and Chauhan (1967); Zilversmit, (1950); Wood (1980); Trinder (1969); Reitman and Frankel, (1957) respectively using the specific kits. While BHB Kits was used for estimation of Beta Hydroxy Buteric acid. These kits was obtained from Sigma, USA according to (Mercer et al., 1986). The NEFA anslysed according to the method of (Duncombe, 1964).

Detection of first estrous in all groups was recorded, also post partum periods and conception rates was recorded for each group after parturition.

\section{Statistical analysis}

The data obtained were analyzed statistically for the mean and standered error (S.E.) for each group. Test of significance ( $\mathrm{T}$ test) was achieved according to Snedecor and Cochran (1989).

\section{RESULTS}

The prophylacted does shows a good health and body condition score condititions, while control non treated groups shows signs of moderately ketosis like weakness, inability to stand, sterna recumbency, incoordination and anorexia.

The obtained results of serum biochemical analysis of the control and treated groups were illustrated in Tables (1,2 and 3).

Table 1 declared that the blood calcium level of propylene treated group (G3) giving the highest significant $(\mathrm{P}<0.05)$ mean $(11.5 \pm 0.42)$ followed by monensin treated group $(10.4 \pm 0.34)$, while the non treated control group (G1) giving the low calcium level $(8.36 \pm 0.42)$. Meanwhile blood phosphorous level in monensin treated group (G2) revealed the highest degree followed by G3 then control group G1 $(5.52 \pm 0.33, \quad 4.22 \pm 0.34$ and $3.86 \pm 0.32 \mathrm{mg} / \mathrm{dl}$ respectively). 
On the other hand, the concentration of blood urea nitrogen in control group was significantly $(\mathrm{P}<0.05)$ increased than monensin and propylene treated groups $(30.95 \pm 0.38, \quad 27.05 \pm 1.5$ and $26.05 \pm 1.5 \mathrm{mg} \%$ respectively). On the other hand, blood total cholesterol concentration in group 3 revealed a highest level followed by group 2 and the lowest cholesterol concentration was showed in group 1 (67.0 \pm 2.84 , $64.0 \pm 1.43$ and $59.0 \pm 2.89 \mathrm{mg} \%$ respectively).

The obtained results in Table 2 revealed different values of the analyzed parameters of the treated and control groups. The liver transaminases widely differs along all groups in which blood serum aspartate amino-transferase (AST) in control group G1 getting the highest significant $(\mathrm{P}<0.05)$ values, but the monensin and propylene $(\mathrm{G} 2, \mathrm{G} 3)$ treated groups having no significant $\quad(\mathrm{P}<0.05) \quad$ differences $(37.16 \pm 2.24, \quad 31.54 \pm 2.13$ and $30.54 \pm 2.43 \mu / 1$ respectively), while (ALT) in group 3 giving the lowest significant $(\mathrm{P}<0.05)$ value followed by group 2 (27.05 \pm 0.81 and $28.04 \pm 0.72)$ while group 1 getting the highest significant $(\mathrm{P}<0.05)$ values $(34.0 \pm 1.83)$.

Also Table 2 illustrates undulated values of thyroid hormones between different groups, in which T3 levels having no significant $(\mathrm{P}<0.05)$ differences between group 1 and group $2(1.85 \pm 0.06$ and $1.53 \pm 0.03 \mathrm{nmol} / \mathrm{l})$ but has a low significant $(\mathrm{P}<0.05)$ value with group 3 which giving the lowest level $(0.34 \pm 0.01 \mathrm{nmol} / \mathrm{l})$. On the other hand $\mathrm{T} 4$ revealed the highest values in group 1 followed by group 2 and group $3(52.0 \pm 4.0,49.2 \pm 3.52$ and $47.3 \pm 2.53 \mathrm{nmol} / 1$ respectively). Meanwhile the insulin level in blood of group 3 having a significant $(\mathrm{P}<0.05)$ increase
$(4.60 \pm 0.35 \mathrm{ng} / \mathrm{ml})$ followed by group $2(3.24 \pm 0.34$ $\mathrm{ng} / \mathrm{ml}$ ) while the lowest value was cleared in group 1 $(2.30 \pm 0.26 \mathrm{ng} / \mathrm{ml})$.

Table 3 declared that the concentration of total blood glucose in propylene treated group G3 giving a highly significant $(\mathrm{P}<0.05)$ results if it is compared with group 2 and control group $1(52.35 \pm 1.8,49.68 \pm 1.7$ and $46.80 \pm 1.6 \mathrm{mg} \%$ respectively). The serum concentration of triglyceride in group 3 resembling the significant $(\mathrm{P}<0.05)$ increase then group 2 and group 1 $(56.0 \pm 1.15,53.0 \mathrm{v} 2.14$ and $42.0 \pm 2.34 \mathrm{mg} \%$ respectively). Otherwise the concentration of Beta Hydroxy Buteric acid (BHB) in serum of control group showed a slight significant $(\mathrm{P}<0.05)$ differences if it is compared with group 2 and group 3 in which there seems to be similar in serum concentrations $(0.76 \pm 0.10,0.47 \pm 0.10$ and $0.45 \pm 0.94 \mathrm{mmol} / \mathrm{l}$ respectively). On the other hand there is no significant $(\mathrm{P}<0.05)$ differences between treated and control groups in analysis of Non estratified Fatty Acids (NEFA) $(0.34 \pm 0.22,0.19 \pm 0.23$ and $0.31 \pm 0.25$ $\mathrm{mmol} / \mathrm{l}$ respectively).

Table 4 explain what happen in post partum periods in does treated by monensin and propylene glycol in which the shortest period of open days was cleared in propylene treated group $(69.8 \pm 2.4)$ followed by Monensin treated group ( $86.6 \pm 2.3$ days) while the largest open days was found in control group (88.7 \pm 3.7 days). On the other side the conception rates was significantly $(\mathrm{P}<0.05)$ increased in group 3 then group $2(84.45$ and $80.4 \%)$, but the lowest conception rate was cleared in group $1(77.8 \%)$.

Table 1: Biochemical changes in calcium, phosphorus, urea and cholesterol of the control and treated groups in does.

\begin{tabular}{lcccc}
\hline Groups & Calcium mg/dl & Phosphorus mg/dl & Urea mg\% & \multicolumn{2}{c}{ Totalcholesterol } \\
$\mathrm{mg} \%$
\end{tabular}

*Means with different subscripts $(a, b, c)$ in the same column were significantly differ at $(\mathrm{P}<0.05)$.

Table 2: Values of liver transaminasis, thyroid hormones and insulin in the control and treated groups in does.

\begin{tabular}{lccccc}
\hline Groups & AST $\mu / 1$ & ALT $\mu / 1$ & T3 nmol/l & T4 nmol/l & $\begin{array}{c}\text { Insulin } \\
\mathrm{ng} / \mathrm{ml}\end{array}$ \\
\hline Gr. 1 & $37.16 \pm 2.24 \mathrm{a}$ & $34 \pm 1.83 \mathrm{a}$ & $1.85 \pm 0.06 \mathrm{a}$ & $52.0 \pm 4.0 \mathrm{a}$ & $2.30 \pm 0.26 \mathrm{c}$ \\
\hline Gr.2 & $31.54 \pm 2.13 \mathrm{~b}$ & $28.04 \pm 0.72 \mathrm{~b}$ & $1.53 \pm 0.03 \mathrm{a}$ & $49.2 \pm 3.52 \mathrm{~b}$ & $3.24 \pm 0.34 \mathrm{~b}$ \\
\hline Gr.3 & $30.54 \pm 2.43 \mathrm{~b}$ & $27.05 \pm 0.81 \mathrm{c}$ & $0.34 \pm 0.01 \mathrm{~b}$ & $47.3 \pm 2.53 \mathrm{c}$ & $4.60 \pm 0.35 \mathrm{a}$ \\
\hline
\end{tabular}

*Means with different subscripts $(a, b, c)$ in the same column were significantly differ at $\mathrm{P}<0.05)$. 
Assiut Vet. Med. J. Vol. 58 No. 135 October 2012

Table 3: Values of blood glucose, triglyceride, BHB and NEFA in the control and treated groups in does.

\begin{tabular}{lcccc}
\hline Groups & Glucose $\mathrm{mg} \%$ & $\begin{array}{c}\text { TotalTriglyceride } \\
\mathrm{mg} \%\end{array}$ & $\begin{array}{c}\text { BHB } \\
\mathrm{mmol} / \mathrm{L}\end{array}$ & $\begin{array}{c}\text { NEFA } \\
\mathrm{mmol} / \mathrm{L}\end{array}$ \\
\hline Gr. 1 & $46.80 \pm 1.6 \mathrm{c}$ & $42 \pm 2.34 \mathrm{c}$ & $0.76 \pm 0.10 \mathrm{a}$ & $0.34 \pm 0.22 \mathrm{a}$ \\
\hline Gr.2 & $49.68 \pm 1.7 \mathrm{~b}$ & $53 \pm 2.14 \mathrm{~b}$ & $0.47 \pm 0.10 \mathrm{ab}$ & $0.19 \pm 0.23 \mathrm{a}$ \\
\hline Gr.3 & $52.35 \pm 1.8 \mathrm{a}$ & $56 \pm 1.15 \mathrm{a}$ & $0.45 \pm 0.94 \mathrm{ab}$ & $0.31 \pm 0.25 \mathrm{a}$ \\
\hline
\end{tabular}

*Means with different subscripts $(\mathrm{a}, \mathrm{b}, \mathrm{c})$ in the same column were significantly differ at $\mathrm{P}<0.05)$.

Table 4: Open days and Conception rates in the control and treated groups in does.

\begin{tabular}{|c|c|c|}
\hline Groups & Open days & C.R.\% \\
\hline Gr. 1 & $88.7 \pm 3.7 \mathrm{a}$ & $77.8 \% \quad \mathrm{c}$ \\
\hline Gr.2 & $86.6 \pm 2.3 b$ & $80.4 \%$ \\
\hline Gr.3 & $69.8 \pm 2.4 \mathrm{c}$ & $85.45 \%$ \\
\hline
\end{tabular}

*Means with different subscripts $(a, b, c)$ in the same column were significantly differ at $\mathrm{P}<0.05)$.

\section{DISCUSSION}

Lamb losses forms a problems occurring during the last 2 to 4 weeks of gestation in ewes and does. Negative energy balance resulting from increased energy demands of rapid fetal growth in late gestation and insufficient food intake was the main cause of lamb losses in ewes and does. The incidence of pregnancy toxemia is greater in ewes with more than one fetus. Poor quality feed, cold weather, lack of exercise and stress of transportation also may increase the incidence of pregnancy toxemia in does (Bradford and Smith, 1990).

In present study the calcium and glucose follows the same manner in which the levels increases after giving propylene glycol. This agrees with Studer et al. (1993) where they indicated that Propylene glycol is an effective glucogenic agent. This increasing level could be a result of increased gluconeogenesis, glycogenolysis, or both, stimulated by catecholamines and glucocorticoids (Norman and Litwack, 1987). The results revealed that glucose concentrations were slightly affected by monensin treated does. Duffield et al. (1998) found that a significantly higher glucose levels in cows treated with monensin. Monensin could increase the concentrations of glucose in several ways and is known to increase propionic acid in the rumen (Richardson et al., 1976). The end results of propionate metabolism is a net increase in oxaloacetate and glucose (Lean et al., 1992). However, Stephenson et al. (1997) suggested that the prepartum glucose generated by monensin was most likely going to the fetus.

A significant reduction of total serum cholesterol level in the control non treated group in this study may be due to disturbance of metabolism in liver with fat infiltration (El- Bealawy, 2000). These results are rather similar to those obtained by (El-Sayed and Siam, 1994) and (Nasr et al., 1997).

There was a significant decrease in the concentration of total triglycerides in control group in this study. Such decrease may be due to increase uptake of lipid by hepatic cells leading to hepatic lipidosis with consequent reduction in hepatic output of triglycerides with reducing the level of circulating triglyceride. Present results were in agreement with those reported by Smith et al. (1997) and Ali (2003) who proved that during pregnancy toxemia, there is usually increased mobilization of Non-Esterified Fatty acids (NEFA) from adipose tissues, which leads to deposition of triglycerides within the hepatocytes and consequently reduces the levels of triglycerides (Vermunt, 2003).

Regarding urea concentrations in blood, present study clarified that in monensin feeding does decreases urea level. This agrees with Ricke et al. (1984) who cited that cattle fed no monensin tend to have higher ruminal ammonia concentration, which probably resulted in greater transfer of ammonia into the blood and a subsequent greater loss of nitrogen in urine. Monensin reduced ruminal NH3 concentration (Horton and Stockdale, 1981), primarily by inhibiting deamination and proteolysis of dietary protein (Whetsone et al., 1981).

Results of serum inorganic phosphorous concentrations in response to monensin are in harmony with those reported by Kirk et al. (1985) who recorded the apparent increase in absorption and retention of phosphorous of animals fed with monensin. Droke et al. (1989) found that feeding of monensin to crossbred lambs increased the absorption of phosphorous. This also agrees with Spears et al. (1987) and Badawy (1992). 
Regarding NEFA and BHBA and there relations to insulin in our results revealed that there were significant increase of insulin in propylene followed by monensin more than control. On the other hand NEFA and BHBA has a mild effects when giving propylene glycol and monensin at the late stage of pregnancy in does, this agree with (Hoedemaker et al., 2004; Juchem et al., 2004) who have shown increases in insulin and subsequent decreases in NEFA and BHBA concentrations by supplementation of propylene. Chung et al. (2009) said that, responses of plasma NEFA concentration to propylene supplementation showed no differences among treatments.

Propylene glycol seemed to exert a greater effect on NEFA via insulin during extensive body fat mobilization. NEFA are used for oxidative metabolism by some tissues and are incorporated into milk fat; however, excessive mobilization of NEFA results in accumulation of triglycerides in the liver and is detrimental to overall cow health and performance (Drackley et al., 2001). Studer et al. (1993) cited that the relative contribution of the gradual increase in plasma NEFA concentration prior to parturition, or the acute surge at parturition, to development of hepatic triglyceride accumulation is not known.

Marked reduction in thyroid hormones was recorded in toxemic cases with inverse relationship between T3 and cholesterol (El- Fayoumy et al., 2006). This agree with Abdou and Iman, (2004) who explained that the pregnancy toxemia affected does are suffering from hypothyroidism and the inverse relation between T3 and cholesterol in poor condition animals was recorded by Baraka and Illek, (2003).

Regarding transaminases activities (ALT, AST) in present results, there was a significant elevation in their activities in the control group in comparison to other treated groups. These results coincided with that previously reported by Radostits et al. (2000) in sheep and Abdou (1995) in goat.

Increased serum enzyme activities of Aspartate Amino transferase (AST) and Alainine Amino transferase (ALT) could throw some light on the hepatic origin of caprine ketosis due to fatty mobilization in the body. These results were in agreement with that mentioned by Sakai et al. (1996) and Omran et al. (2000). The elevation of the liver enzymes is an important diagnostic index in the diseases of liver and biliary system which indicate the presence of liver damage or disruption of hepatic cells due to progressive accumulation of lipid granules, with subsequent increased permeability and leakage of these enzymes into the blood (Radostits et al., 2002 and Yao et al., 2003).

Reproduction in farm animals is closely related with dynamic activity of the thyroid functions (Afiefy, 1966). Azouz et al. (1989) observed that decrease of $\mathrm{TSH}$ and triiodothyronin in post-partum goats may indicate the independence of follicular growth from increasing levels of thyroid hormones during post partum period.

Present results revealed that conception rates in propylene supplemented group were significantly increased. This agreed with Roche et al. (2000) who cited that ketosis results from energy balance defect, has a deleterious effects on follicular growth and CL activity. After oral administration, a portion of propylene is metabolized to propionate (Emery et al., 1964), but the majority of propylene escapes the rumen untransformed to be converted to glucose by the liver, primarily via the lactaldehyde pathway and subsequent oxidation to lactate (Miller and Bazzoano, 1965). Propionate is transported to the liver through the portal system, where it is transformed into pyruvate and eventually glucose via oxalacetate Moore and Ishler (1997).

Regarding open days, the ovarian activity of propylene treated group was highest and giving the lowest duration of open days more than monensin and control groups. Follicle recruitment (Spicer et al., 2002) as well as follicular growth and differentiation (Spicer and Echternkamp, 1995) are stimulated by insulin, which exerts a beneficial influence on the subsequent embryonic development (Telfer et al., 1999). Insulin stimulates the in vitro proliferation and function of granulosa and theca cells (Spicer et al., 1993).

Changes in blood insulin level are closely related to IGF-I concentrations (O'Callaghan and Boland, 1999). Together, insulin and IGF-I affect ovarian function and early embryo development by means of a potent stimulation of bovine granulosa cells (Alvarez et al., 2000), and lead thecal cells to proliferate. On the contrary, with low levels of both IGF-I and insulin, the follicle does not produce adequate levels of estradiol or grow to a size able to trigger the LH surge and ovulation (Beam and Butler, 1999).

From this study, it can be concluded that, under local mangemental and environmental conditions, propylene glycol and monensin can be used safely as a fed supplement for pregnant does at late stages of pregnancy. The both components could help as a prophylactic measure from lamb losses and for improving fertility in term of decreasing open days as well as increasing percentages of conception rates.

\section{REFERENCES}

Abdou, T.A. (1995): Studies on pregnancy toxaemia in goats using isotopes. Thesis Ph. D. Vet. Sci., Cairo Univ.

Abdou, T.A. and Iman, B.S. (2004): Pregnancy toxaemia inducing congenital goiter in goats. $\mathrm{J}$. Egypt. Vet. Med. Assoc. 64(6): 55.

Afiefy, M.M. (1966): Seasonal variations in thyroxine and iodine contents in relation to fertility and 
infertility in the Egyptian buffaloes. Vet. Med. J., 14: 73.

Ali, A.A. (2003): Field studies on ketosis in ruminants and biochemical aspects. The $2^{\text {nd }}$ scientific congress for provincial laboratories 7-10 September (2003).

Alvarez, P.; Spicer, L.J.; Chase, J.C.C.; Payton, M.E.; Hamilton, T.D. and Stewart, R.E. (2000): Ovarian and endocrine characteristics during an estrous cycle in Angus, Brahman, and Senepol cows in a subtropical environment. J. Anim Sci.78(5): 1291.

Azouz, A.M.; Yonis, M.Y.; Mekkawy, H.A.H.; Salem, R.H. and Yossef, Farahat, A.A. (1989): Estradiol, progesterone, thyrotrofic and thyroid hormones concentrations during the post partum period in goats. Vet. Med. J. Giza, 1: 133-142.

Badawy, E.A.H. (1992): Some biological effects of rumen fermentation modifier (Monensin) of buffalo-heifers with special reference to sexual puberty. Ph. D. Vet. Sci. (Physiology) Fac. Vet. Med., Cairo Univ.

Baraka, T.A. and Illek, J. (2003): Clinical investigation of thyroid hormones profile as a diagnostic aspect in camels (Camelus dromedarius). J.Egypt. Vet.Med.Assoc.63: 297.

Bartley, E.E.; Herod, E.L.; Bechtle, R.M.; Sapienze, D.A.; Brent, B.E. and Davidovich, A. (1979): Effects of monensin or lasalocid, with and without niacin or amicloral, on rumen fermentation and feed efficiency. J. Anim. Sci., 49: 1066-1075.

Beam, S.W. and Butler, W.R. (1999): Effects of energy balance on follicular development and first ovulation in postpartum dairy cows. J. Reprod. Fertil. Suppl; 54: 411-24.

Bergan, W.G. and Bates, D.B. (1984): Ionophores: There effect on production efficiency and mode of action. J. Anim. Sci: 1465.

Bergman, E.N. (1973): Glucose metabolism in ruminants as related to hypoglycemia and ketosis Cornell. Vet. 63: 341-382.

Blood, D.C. and Radostitis, O.M. (1991): Veterinary Medicine Bialiere Tindall $6^{\text {th }}$ Ed. 1129-1137.

Bradford, P. and Smith, B. (1990): Large Animal Internal Medicine the C.V. Mosby company,Philadelphia, Toronto.

Cheema, H.; Ashig, S.; El-Amrousi, M. and ElGharram, M. (1985): Pregnancy toxemia in goat. Index to Research Paper, College of Vet. Med.and Animal Resources, Saudia Arabia, p. 104.

Christensen, G.O.; Grummer, R.R.; Rasmussen, F.E. and Pertics, S.G. (1997): Effect of method of delivery of propylene glycol on serum metabolites of feed- restricted cattle. J. Dairy Sci. 80: 563-568.(abstract).

Chung, Y.-H.; Brown, N.E.; Martinez, C.M.; Cassidy, T.W. and Varga, G.A. (2009): Effects of rumen-protected choline and dry propylene glycol on feed intake and blood parameters for Holstein dairy cows in early lactation J. Dairy Sci. 92: 2729-2736.

Czerkawski, J.W. and Breckenridge, G. (1972): Fermentation of various glycolytic intermediates and other compounds by rumen micro- organisms, with particular reference to methane production. Br. J. Nutr. 27: 131-146.

Drackley, J.K.; Overton, T.R. and Douglas, G.N. (2001): Adaptations of glucose and long-chain fatty acid metabolism in liver of dairy cows during the periparturient period. J. Dairy Sci. 84(E. Suppl.): E100-E112.

Droke, E.A.; Spears, J.W.; Armstrong, J.D. and Kegley, E.B. (1989): Effect of feeding monensin on mineral metabolism in lambs unadapted and adapted to monensin. J. Anim. Sci., (Supp. 1): 567. (Abestract).

Duffield, T.f. and Bagg, R.N. (2000): Use of Ionophores in lactating dairy cattle: A review Can. Vet. H., 41: 388-394.

Duffield, T.F.; Sandals, D.; Leslie, K.E.; Lissemore, K.; McBride, B.W.; Lumsden, J.H.; Dick, P. and Bagg, R. (1998): Effect of prepartum administration of monensin in a controlledrelease capsule on postpartum energy indicators in lactating dairy cows. J. Dairy Sci., 81 (1998), pp. 2354-236.

Duncombe, W.G. (1964): Calorimetric micro determination of non estratified free fatty acids in serum. Clinic. Chem. Acta., 9: 122-125.

El-Bealawy, M.A. (2000): Some studies on pregnancy toxaemia in goats. Egypt. J. Agric. Res.78 91) 207: 215 .

El-Fayoumy, M.M.; Baraka, T.A. and Abdel-Halim, M.M. (2006): Clinical and laboratory studies on caprine pregnancy toxaemia in relation to haemonchosis as a mayor contributing factor. J. Egypt Vet. Med. Assoc. 66, 3: 239.

El-Sebaie, A. (1992): Pregnancy toxemia in goats and sheep: Clinical updating. Proc. $5^{\text {th }}$ Sci. Cong., Fac. Vet. Med., Assiut University, Nov. 8-10, Vol. 2: 9-12.

El-sayed, R.F. and Siam, A. (1994): Pregnancy toxaemia in ews. (a trial of treatment). Alex.J. Vet. Sci., 1: 31-35.

Emery, R.S.; Burg, N.; Brown, L.D. and Blank, G.N. (1964): Detection, occurrence, and prophylactic treatmentof borderline ketosis with propylene glycol feeding. J. Dairy Sci. 47: 1074.

Haimoud, D.A.; Vernay, M.; Bayourthe, C. and Moncoulon, R. (1995): Avoparcin and monensin effects on the digestion of nutrients in dairy cows fed a mixed diet. Can. H. Anim. Sci., 75: 379-385.

Haney, M.E. and Hoehn, M.M. (1967): Monesin, anew biologically active compound, Antimicrob, Agents chemother., 1: 349. 
Hanzlik, P.J.; Lehman, A.J.; Van Winkle, Jr.W. and Kennedy, N.K. (1939): General metabolic and glycohenic actions of propylene glycol and some other glycols. J. Pharmacol. Exp. Ther. 67: 114-126.

Heitzman, R.J. and Herriman, I.D. (1977): The response of sheep with pregnancy toxemia to trenbolon acetate. Vet. Rec., 100: 317-318.

Herdt, T.H. and Emery, R.S. (1992): Therapy of diseases of ruminant intermediary metabolism. Vet. Clin. Of North America: Food Animal Practice, (1): 91.

Hoedemaker, M.; Prange, D.; Zerbe, H.; Frank, J.; Daxenberger, A. and Meyer, H.H.D. (2004): Perepartal propylene glycol supplementation and metabolism, animal health, fertility, and production in dairy cows. J. Dairy Sci. 87: 2136-2145.

Horton, G.M.J. and Stockdale, P.H.G. (1981): Lasalocid and monensin in finishing diets for early weaned lambs with naturally-occuring coccidiosis. Am. J. Vet. Res., 42: 433.

Johnson, R.B. (1954): The treatment of ketosis with glycerol and propylene glycol. Cornell Vet. 44: 6-21.

Juchem, S.O.; Santos, F.A.; Imaizumi, H.; Pires, A.V. and Barnabe, E.C. (2004): Production and blood parameters of Holstein cows. Treated prepartum with sodium monensin or propylene glycol. J. Dairy Sci. 87: 680-689.

Kirk, D. J.; Greene, L.W.; Schelling, G.T. and Byers, F.M. (1985): Effects of monensin on $\mathrm{Mg}, \mathrm{Ca}$, $\mathrm{P}$, and $\mathrm{Zn}$ metabolism and tissue concentration in lambs. J. Anim.Sci., 60: 1485.

Kronfeld, D.S. (1972): Ketosis in pregnant sheep and lactating cows: A review. Aust. Vet. J., 48: 680-687.

Lean, I.J.; Bruss, M.; Baldwin, R.L. and Troutt, H.F. (1992): Bovine ketosis: a review II. biochemistry and prevention. Vet. Bull., 62: $1-14$.

Marteniuk, J.V. and Heirdt, T.H. (1988): Pregnancy toxemia and ketosis of ewes and does. Vet. Clin. North. Amer. Food Animal Practice. 4: 307-315.

Mercer, D.W.; Losos, F.J. and Mason, L. (1986): Monitoring therapy with saline in Ketoacidotec patients by quantifying 3hydroxybutyrate with a commercial kit. Lin. Hem., 32: 225.

Mgtowan, M.W.; Artiss, I.D.; Standbergh, D. and Zark, B. (1983): Aperoxidase- coupled method for colorimetric determination of serum triglycerides. Clin. Chem. 29: 538.

Miller, O.N. and Bazzano, G. (1965): Propanediol metabolism and its relation to lactic acid metabolism. Ann. New York Acad. Sci. 119: 957.
Moore, D.A. and Ishler, V. (1997): Managing dairy cows during the transition period: focus on ketosis. Vet. Med.; 92: 1061-72.

Nasr, M.Y.; Foad, F.M. and El Saidy, B.E. (1997): Studies on pregnancy toxaemia in does. Alex. J. Vet. Science, Vol. 13, No. 507-514.

Norman, A.W. and Litwack., G. (1987): Adrenal corticoids. Page 412 in Hormones. Academic Press, San Diego, CA.

O'Callaghan, D. and Boland, M.P. (1999): Nutritional effects on ovulation, embryo development and the establishment of pregnancy in ruminants.J. Anim. Sci. 68: 299-314.

Omran, H.H.; Selim, A.M. and El- Kholany, K. (2000): Studies on liver affections in farm animals in Sharkia Governorate. Egypt. J. Comp Path. and Clin. Path., 13(1).

Radostits, O.M.; Blood, D.C. and Gay, C.C. (2002): Veterinary Medicine, $10^{\text {th }}$ edition, p.p.1343, Bailliere Tindall, London, Tokyo, Philadelphia.

Radostits, O.M.; Gay, C.C. and Blood, D.C. (2000): Veterinary Medicine (A text book of the disease of cattle.) $9^{\text {th }}$ ed. ELBS. The English language book Society.

Reitman, A. and Frankel, S. (1957): A colorimetric method for the determination of serum transaminases. Am. J. Clin. Path., 28: 56.

Richardson, L.F; Raun, A.P.; Potter, E.L.; Cooley, C.O. and Rathmacher, R.P. (1976): Effect of monensin on rumen fermentation in vitro and in vivo. J. Anim. Sci., 43: 657-664.

Ricke, S.C.; Berger, L.I.; Van deraer, P.J. and Fahey, G.C. (1984): Effects of lasalocid and monensin on nutrient digestion, metabolism and rumen characteristics of sheep. J. Anim. Sci., 58: 194.

Roche, J.F.; Mackey, D. and Diskin, M.D. (2000): Reproductive management of postpartum cows. Anim. Reprod. Sci.; 60: 703-712.

Sakar, B.C. and Chauhan, U.P.S. (1967): Colorimetric method for determination of serum calcium. Annal. Biochem. 20: 155.

Sakai, T.; Hamakawa, M. and Kubo, S. (1996): Glucose and xylitol tolerance tests for ketotic and healthy dairy cows. J. Dairy Sci., 79 (3): 372.

Schelling, G.T. (1984): Monensin: mode of action in the rumen. J. Anim. Sci., (58): 1518.

Smith, T.R; Hippen, A.R.; Beitz, D.C. and Young, T.W. (1997): Metabolic characteristics of induced ketosis in normal and obese dairy cows. J. Dairy Sci.; (8o): 1569.

Snedecor, G.W. and Cochran, W.C. (1989): Statistical methods. $8^{\text {th }}$ Ed., Ames.Iowa. The Iowa state university. Press, USA.

Spears, J.W.; Burns, J.C. and Schricker, B. R. (1987): Lysocellin and monensin effects on mineral metabolism in steers fed green chop. J. Anim. Sci., 65: 445. (Abstract).

Spicer, L.J; Alpizar, E. and Echternkamp, S.E. (1993): Effects of insulin, insulin-like growth factor-1 
and gonadotropins on bovine granulose cell proliferation, progesterone production, and (or) insulin-like growth factor-I production in vitro. J. Anim. Sci.,71: 1232-41.

Spicer, L.J.; Chamberlain, C.S. and Maciel, S.M. (2002): Influence of gonadotropins on insulinand insulin-like growth factor-I (IGF-I) induced steroid production by bovine granulosa cells. Domest. Anim. Endocrinol;22: 237-54.

Spicer, L.J. and Echternkamp, S.E. (1995): The ovarian insulin and insulin-like growth factor system with an emphasis on domestic animals. Domest. Anim. Endocrinol; 12: 223-45.

Stephenson, K.A.; Lean, I.J.; Hyde, M.L.; Curtis, M.A.; Garvin, J.K. and Lowe, L.B. (1997): Effects of monensin on the metabolism pf periparturient dairy cows. J. Dairy Sci., 80, pp. 830-837.

Studer, V.A.; Grummer, R.R.; Bertics, S.J. and Reynolds, C.K. (1993): Effect of prepartum propylene glycol administration on periparturient fatty liver in dairy cows. J. Dairy Sci. 76: 2931-2939.

Telfer, E.E.; Webb, R.; Moor, RM. and Gosden, R.G. (1999): New approaches to increasing oocyte yield from ruminants. J. Anim. Sci.; 68: 285.

Trinder, P. (1969): Determination of glucose in blood using glucose oxidase with an alternative oxygen acceptor. Ann. Clin. Biochem. 6: 24-27.

Tyler, J.W.; Wolfe, D.F. and Maddox, R. (1992): Clinical indications for dietary ionophores in ruminants, Compend. Contin. Educ. Pract. Vet., 14: 989-993.

Van Maanan, R.W.; Herbein, J.H.; Mcgilliard, A.D. and Young, J.W. (1978): Effects of monensin in vivo rumen propionate production and blood ketones in cattle. J. Nutr., 108: 1002-1007.

Vermunt, J. (2003): A brief review and observations on clinical ketosis in non-lactating dairy cattle. New Zealand Vet. J. 35:1 21.

Waston, D. (1960): Determination of total cholesterol. Clin. Chem. Acta. 5: 637.

Whetsone, H.D.; Davis, C.L. and Bryant, M.P. (1981): Effect of monensin on breakdown of protein by ruminal microorganisms in vitro. J. Anim. Sci., 53: 803 .

Wood, W. J. (1980): A second external quality control survey (EQCS) for serum T3 and T4 assays using the Munich model. J. Clinical and Clinical Biochemistry. 18: 511.

Yao, S.Z.; Gao, S.N. and Wulumuhan, N. (2003): Pathogenetic characteristics and early diagnosis of subclinical ketonaemia in high producing dairy cows. Chinees J. of Vet. Sci. and Technol., 5: 7.

Zapletal, O. (1967): The toxicity of urea and possibility its influence at cattle. Thesis, Brno(Czech Re-public), 120 pp.

Zilversmit, S.A. (1950): Colorimetric method for determination of inorganic phosphorus. J. Lab. Clin. Med. 33: 155.

\footnotetext{
تأثير المونينزن والبروبيلين جليكول كوقاية من تسمم الحمل في الماعز وتأثير هما على نسبة الإخصاب هويدا السبل ، رشاد حامد عثمان

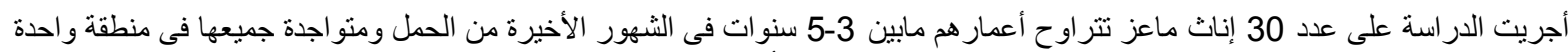

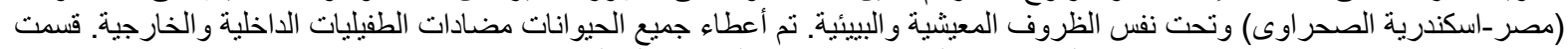

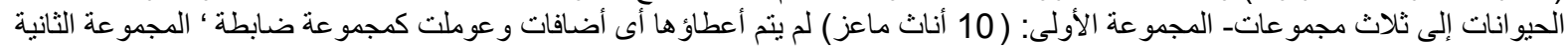

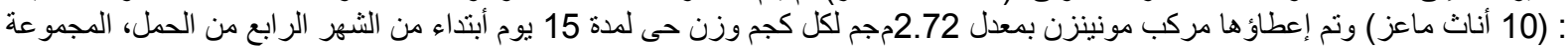

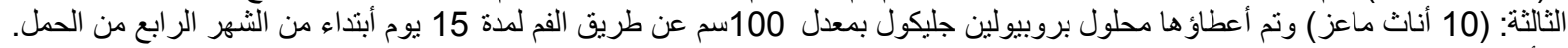

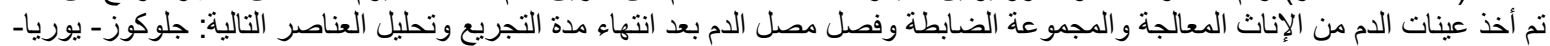

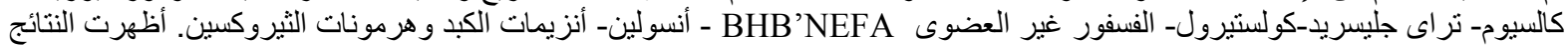

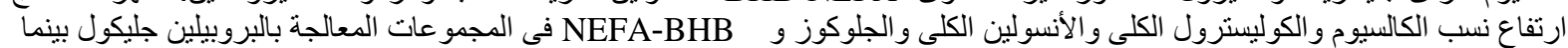

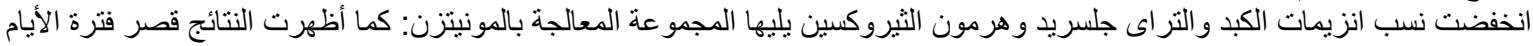

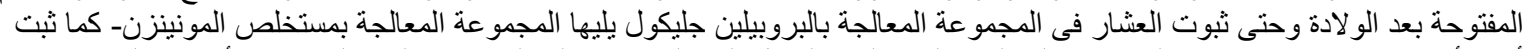

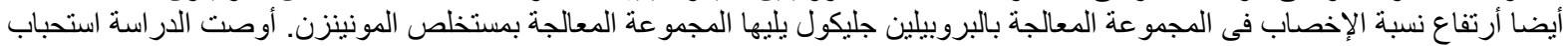

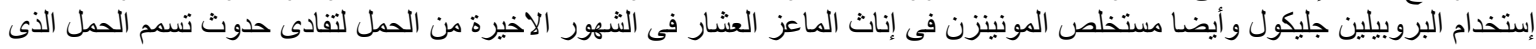

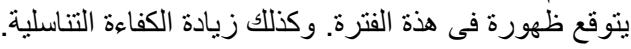

